\title{
Clinical Applications of Office-Based Laryngeal Surgery With KTP Laser
}

\author{
Jung-Hae Cho (D) \\ Department of Otorhinolaryngology-Head and Neck Surgery, College of Medicine, The Catholic University of Korea, Seoul, Korea \\ KTP 레이저를 이용한 외래 기반 후두 수술의 임상적 적용
}

조정해

가톨릭대학교 의과대학 이비인후과학교실

The pulsed photoangiolytic 532-nm potassium-titanyl-phosphate (KTP) laser has emerged in recent years as an efficacious treatment modality for vocal fold lesions. It also has broadened the indications for other laryngeal laser surgery. Features of KTP laser that it is a fiber-based delivery system and its energy is selectively absorbed by oxyhemoglobin make it suitable for office-based laryngeal procedures. An office-based KTP laser surgery provides an alternative management option for benign laryngeal diseases and can be performed comfortably under flexible endoscopic guidance which is placed through the nose of a fully awake patient. Office-based laryngeal surgery with a KTP laser can alleviate the need for general anesthesia. However, there are some limitations to apply due to reduced visual precision and the fact that the vocal folds are moving during procedures. Clinicians should carefully weigh the advantages and disadvantages of office-based procedures before a treatment option is selected. Patient selection and standardized laser energy parameters may help in decreasing complications and improving the treatment results.

Keywords Potassium-titanyl-phosphate; Laser; Vocal polyp; Benign laryngeal lesions; Laryngeal surgery; Office-based surgery.

\section{서 론}

후두 병변을 수술적으로 제거하기 위해서는 전신마취를 한 후 구강을 통해 강직형 후두 내시경을 삽입한 상태에서 수술용 현미경으로 후두 병변을 확대하여 병변을 제거 하는 후두 미세수술이 전통적으로 널리 이용되고 있다. 그러나 개구 장애, 불량한 치아 상태, 고령이나 심혈관계 등 심각한 기저 질환으로 고식적인 전신마취 하의 후두 미세수 술을 적용할 수 없는 환자를 임상에서 종종 접하게 된다. 최근에 혈관 용해성 레이저, 특히 potassium-titanyl-phosphate (KTP, $532 \mathrm{~nm}$ ) 레이저가 도입되어 후두 병변를 치 료하는 적응증이 점진적으로 늘어나고 있다[1]. 후두의 다양한 국소 마취 방법, 고품질 의 전자 내시경 영상 발달, 섬유관을 통한 레이저 전달 기술이 조합되면서 외래 기반의 후두 수술이 보다 용이해지고 있다. 따라서 기존의 수술실에서 하는 전통적인 수술 방
Received December 1, 2021

Revised December 7, 2021

Accepted December 8, 2021

\section{Corresponding Author}

Jung-Hae Cho, MD, PhD

Department of Otolaryngology-

Head and Neck Surgery,

St. Vincent's Hospital,

College of Medicine,

The Catholic University of Korea,

93 Jungbu-daero, Paldal-gu,

Suwon 16247, Korea

Tel +82-31-881-8925

E-mail jhchomd@catholic.ac.kr

\section{ORCID iD}

Jung-Hae Cho (D)

https://orcid.org/0000-0001-9904-7869

This is an Open Access article distributed under the terms of the Creative Commons Attribution Non-Commercial License (https://creativecommons.org/ licenses/by-nc/4.0) which permits unrestricted non-commercial use, distribution, and reproduction in any medium, provided the original work is properly cited. 
법보다 외래에서 간단한 처치 개념으로 KTP 레이저를 적용 하면서 고위험 환자의 전신마취 합병증에 대한 부담뿐만 아 니라 마취 및 관련된 검사 비용도 줄일 수 있다.

외래 기반 후두 레이저 수술은 국내에서 2000년 초반에 처 음으로 585-nm PDL (pulsed dye laser)을 이용하여 시행되 었다[2]. 그러나 짧은 파폭 $(0.5 \mathrm{~ms})$ 과 큰 섬유관 $(0.6 \mathrm{~mm})$ 으로 수술 시에 문제점을 야기하게 되어, 이후 $\mathrm{PDL}$ 레이저의 단점 을 보완하기 위해 2006년에 Zeitels 등[3]이 처음으로 KTP 레이저를 이용하여 외래에서 후두 수술을 시행하였다. 당시 $\mathrm{KTP}$ 레이저는 성대 이형성증과 재발성 호흡기 유두종을 치 료하는데 사용하였다. KTP 레이저를 조사하게 되면 병변 내 의 미세혈관으로 선택적 흡수가 되면서 광응고작용을 일으 켜 병적 혈관을 없앨 수 있다. 본론에서는 현재 시행되고 있는 $\mathrm{KTP}$ 를 이용한 외래 기반 후두 레이저 수술의 적응증과 방법 및 주의 사항에 대해 알아보고자 한다.

\section{본 론}

KTP 레이저는 붉은색을 띄는 물질에 에너지가 잘 흡수되 는 성질이 있기 때문에, 인체의 혈관 혹은 혈관이 풍부한 조직 에 선택적인 광열 분해(photothermolysis)가 잘 일어난다. 따 라서 KTP 레이저의 목표 부위는 직경이 100 마이크론 이하 인 미세 혈관이며, 상피 조직의 손상은 최소화하면서 보존하 고 상피내의 혈관층에 보다 선택적으로 작용하기 때문에 $\mathrm{CO}_{2}$ 레이저에 비해 점막의 손상을 적게 일으킨다. KTP와 같은 혈 관 용해성 레이저인 $\mathrm{PDL}$ 레이저가 조직에 미치는 영향을 알 아 보는 조직학적 검사를 통하여 기저막과 상피 세포 사이의 데스모솜(desmosome) 접합 부위가 레이저에 의해 우선적으 로 파괴되는 것이 확인되었다[4]. 따라서 비정상적 혈관이 병 인이 되는 성대 용종, 혈관 확장증에서 가장 유용하게 KTP 레이저를 적용할 수 있고 그 외에 성대 각화증, 조기 성문암 이나 후두 유두종에서도 사용할 수 있다[5,6]. 레이저 셋팅은 펄스 당 와트 수, 펄스의 지속시간, 초당 펄스 수에 따라 다양하 게 에너지를 병변에 조사할 수 있다. 한편 Mallur 등[7]은 치 료 효과의 표준화를 위하여 KTP 레이저 조사 방법 및 치료 후 병변의 상태에 따라 다음과 같이 5 가지 분류 체계(KTPV, noncontact with angiolysis; KTP1, noncontact mucosal blanching; KTP2, noncontact epithelium disruption; KTP3, contact with epithelial ablation without tissue removal; KTP4, contact with epithelial ablation with subsequent tissue removal)를 제시하였다. 이와 같은 치료의 표준 분류 체 계를 사용하면 수술자 간의 KTP 레이저 치료의 결과를 서로 비교하고, 치료 후 음성 호전 상태 및 재발 여부를 장기적으로
평가하기에 유용할 것으로 기대된다.

\section{KTP 후두 레이저 수술의 적응증 및 장단점}

$\mathrm{KTP}$ 후두 레이저 수술은 혈관성 병변인 작은 성대 용종과 성대의 모세혈관 확장증에 유용하다. 전연합부위에 양측성 병 변이 있을 경우 협착을 예방하기 위해 단계적 수술을 하는 것 이 좋은데, 이런 경우 KTP 레이저를 이용하면 전신마취 없이 외래에서 여러번 수술을 할 수 있는 장점이 있다. 큰 성대 용종 및 부종 또는 백반증, 유두종인 경우에는 한 번의 수술로 모 두 제거되지 않아 여러 번의 수술이 필요할 수 있음을 수술자 와 환자는 인식해야 한다. 한 연구에 의하면 KTP 후두 레이 저 수술 후 약 $20 \%$ 의 환자에서 1년 내에 재치료가 필요하다 고 하였다[8]. 수술 중 성대의 움직임과 레이저 이동 섬유관과 조직과의 거리에 따라 병변에 도달되는 정확한 에너지의 양이 달라질 수 있다. 병변 이외의 주위 조직으로 레이저가 조사되 면 의도하지 않았던 성대 점막하 출혈과 지속적인 성대 부종 을 야기하고 성대 점막 파동을 저해하여 수술 후 목소리 악화 를 일으킬 수 있다[8]. 그러나 이와 같은 현상은 PDL 레이저 보다는 KTP 레이저를 사용하였을 경우보다 적게 일어난다고 알려져 있다[6]. 한편 가장 많은 양성 성대 질환인 성대 결절에 서는 KTP 레이저를 적용하기에는 아직까지 한계가 있다.

\section{수술 전 처치}

수술 중 환자는 침을 삼키거나 기침하는 행동을 자제해야 하기 때문에 타액 또는 점액이 과도하게 분비되어 이를 관리 하기 어려울 수 있어서 아트로핀(atropine) 0.25-0.5 mg을 수 술 10-20분 전에 정맥내 주입하는 것이 도움을 줄 수 있다. 후 두 내시경이나 경비강 식도 내시경이 비강을 통해 접근을 해 야 하기 때문에 항울혈제(phenylephrine)와 국소 마취제( $2 \%$ lidocaine)를 비강내에 분무하여 비강 점막을 수축시키고, 구 역 반사를 억제하기 위해 4\% 리도카인을 구인두 부위에 2-3 회 분무한다. 이후에 후두의 국소마취가 필요한데 $4 \%$ 리도 카인을 에어로졸 형태로 흡입하게 하거나 후두 가글, 즉 발성 하고 있는 상태에서 성대 점막에 국소마취제를 점적하는 방 법을 이용할 수 있다. 이와 같은 후두 국소마취에도 불구하고 외래에서 수술 중 레이저 열이 후두 점막에 도달할 때 통증이 나 불편감을 심하게 일으킬 수 있으므로, 26게이지 주사침을 이용하여 윤상갑상막을 통과하여 성대 점막 아래로 $2 \%$ 리 도카인을 직접 주입하여 성대 점막을 마취함으로써 통증에 예 민한 환자에게 효과적으로 적용할 수 있다. 한편 후두개 낭종 일 경우에는 구강을 통해 주사침이 바로 접근하여 레이저가 도달할 병변 부위의 점막에 국소마취제를 주입하여 처치 시 에 환자의 통증을 줄일 수 있다(Fig. 1). 


\section{KTP 후두 레이저 수술 과정 및 방법}

채널이 있는 후두 내시경 또는 경비강 식도 내시경에 레이 저 섬유관을 삽입한다. 이때 보호용 카테터를 먼저 삽입한 후 에 레이저 섬유관을 넣는 것이 내시경 채널안에 있는 유리관 을 보호할 수 있는 방법이다. 레이저 전달 섬유관의 크기는 $0.6 \mathrm{~mm}$ 정도로 매우 가늘기 때문에 채널을 통해 수술 시 발 생할 수 있는 연기를 효과적으로 흡인을 할 수 있고 비디오 영상의 질도 향상시킬 수 있다. 수술자와 환자는 모두 보안경 을 착용해야 한다. 만일 레이저가 눈에 조사될 경우 망막에 손 상을 줄 수 있기 때문이다. 환자는 진료용 의자에 편하게 앉 은 자세에서 턱을 약간 내민 자세를 취한다. 집도의가 비디오 화면을 보면서 내시경을 삽입한 후 병변이 정확히 노출되면 보조의는 레이저 섬유관을 병변 부위에 접근시킨다(Fig. 2). 보통 비접촉성 방식으로 레이저가 병변으로부터 2-4 mm 정 도 위에 떨어져서 조사하게 된다. 레이저 출력은 병변에 따라

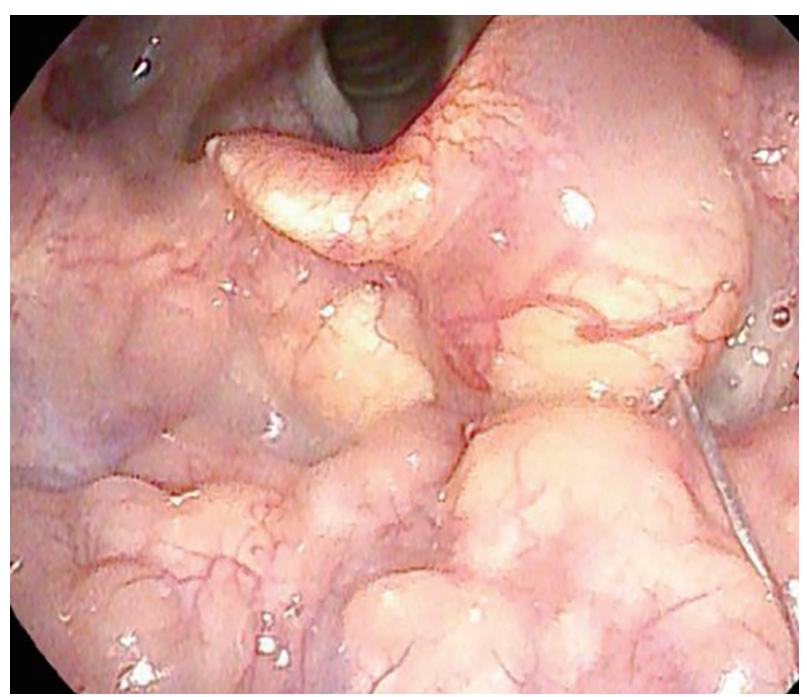

Fig. 1. Direct infiltration of local anesthetic on the epiglottic cyst.
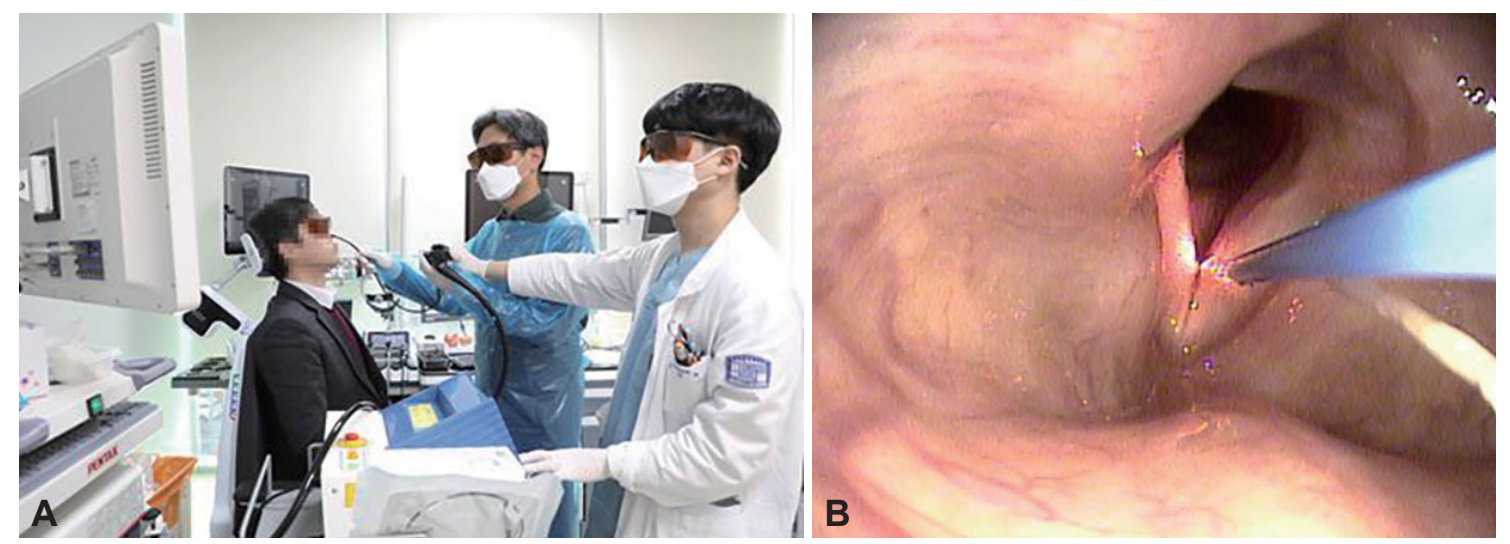

Fig. 2. Patient positioning and equipment set up for office-based potassium-titanyl-phosphate (KTP) laser procedures. A: The patient is seated in the upright position in the examination chair, and the flexible channeled laryngoscope with laser fiber is passed through the nasal cavity. B: When the surgeon identifies the lesion, an assistant locates the laser fiber just above the target lesion. The informed consent was obtained from the patient.

다양하게 조절할 수 있지만, 일반적으로 강도 6-8 W/pulse, 펄스 폭(pulse width) 25-50 ms, 주기 2-20 Hz로 조사한다. 수술은 레이저 열을 받은 성대 용종이 하얗게 탈색되거나 더 진행되어 타서 검게 될 때까지 시행할 수 있다. 용종이 상대적 으로 큰 경우에는 레이저로 주위 혈관을 응고시킨 후 용종이 작아지게 되면 겸자를 이용하여 출혈없이 제거하는 것(endoscopic polypectomy)도 가능하다[9].

\section{성대 용종 및 모세혈관 확장증}

현재까지 성대 용종이 외래에서 시행하는 KTP 후두 레이 저 수술에서 가장 빈번히 적용되고 있는 질환이다. 성대 용종 은 색깔에 따라 출혈성(hemorrhagic) 또는 반투명성(translucent)으로 구별되고 모양에 따라 목이 있거나 없는 용종 (pedunculated, sessile)으로 나눌 수 있다. 일반적으로 크기가 상대적으로 작거나 출혈성 형태의 성대 용종이 KTP 레이저 수술에 더 반응을 잘 한다. 용종이 큰 경우에는 주위 혈관을 광응고시키면 용종으로 가는 혈관이 폐색되어 시간이 지나 면서 점점 크기가 작아져 퇴화하여 사라지는 경과를 거친다. 술자에 따라서는 레이저를 조사하여 용종의 혈관을 검게 소 작한 후 남은 부위를 겸자로 제거하는 용종 절제술을 동시에 할 수도 있다고 하였다[9]. 그러나 이런 경우에는 레이저 열이 보다 많이 전달되기 때문에 정상 주위 조직도 같이 손상을 받 아 성대 점막이 경화되어 점막 파동이 감소되는 부작용을 일 으킬 수 있으므로 주의가 필요하다. 레이저를 이용한 성대 용 종 절제술과 고식적인 현미경하 후두 미세수술의 결과를 비교 한 보고에 따르면 두 군에서 모두 수술 후 음성 호전을 보였 으며 호전 정도에는 차이가 없었다[10].

성대의 모세혈관 확장증(capillary ectasia)은 일반적으로 성대 용종만큼 뚜렷한 쉰 목소리는 없지만, 전문적 음성 사용 자들에게는 반복적인 목소리 변화를 야기할 수 있다. 기존의 
후두미세수술로 병적 혈관을 제거하는 방법을 사용할 수 있 지만, 정상 점막을 절개하므로 수술 후 음성 변화가 생길 수 있다. 이 질환은 혈관에 선택적으로 흡수되는 KTP 레이저를 외래 기반으로 사용함으로써 전신마취 없이 빠른 음성 회복과 완전한 병적 혈관의 제거가 가능하다. 가수를 대상으로 한 전 향적 연구에서도 혈관 용해성 레이저로 수술하여 모든 환자 들이 특별한 합병증 없이 완전한 음성 회복의 결과를 보고하 였다[6]. 수술 시에는 비접촉 모드를 사용하고 병적 혈관이 탈색될 정도만 레이저를 조사한다.

\section{후두개 낭종 및 성대 접촉성 육아종}

우연히 발견되거나 경부 이물감으로 발견된 후두개 낭종을 위한 치료로써, 과거에는 전신마취 하에서 후두 현수현미경 하 에 레이저를 이용하여 절제하는 것이 일반적인 치료 방법이었 다. 이와 같은 방법으로 완전 절제는 가능하나 수술 후 약 일 주일 동안 연하통과 이물감을 호소하는 경우가 많았다. 드물 지만 수술 부위의 출혈로 응급 상황이 오는 경우나 과도한 절 제로 인하여 인두협착으로 술 후 지속적인 인두 불편감을 초 래할 수 있다. 그러나 최근 외래에서 KTP 레이저를 이용하여 낭종 조대술을 시행함으로써 환자의 통증과 빠른 회복을 도 모할 수 있게 되었다[11]. 후두개 낭종은 조직학적으로 일종의 가성 낭종(pseudocyst) 또는 저류낭이므로 낭내의 저류 물질 이 배액 될 수 있는 통로를 레이저를 통해 만들어 주는 조대 술을 시행함으로써, 저절로 퇴화되어 없어지는 효과를 얻을 수 있다. 현재까지는 표준 치료로 인정되고 있지는 않지만, 전신 마취를 하기 힘들거나 강직형 후두경으로 노출이 어려운 매우 큰 후두개 낭종일 경우, KTP 레이저를 이용한 후두개 낭종 의 조대술도 하나의 대안이 될 수 있다. 본 저자도 추적 기간 이 비록 2년 내로 짧지만, 약 15예의 후두개 낭종을 조대술하 여 모두 재발없이 경과 관찰하고 있다.

피열 연골의 성대 돌기(vocal process)에 궤양이 발생하면
이 부위에 육아종이 형성되면서 음성 변화, 만성 기침 및 이 물감을 일으키는 질환이 성대 접촉성 육아종이다. 음성치료, 양성자 펌프 억제제, 보툴리눔 독소 또는 스테로이드 주입술 등 다양한 치료 방법이 적용되고 있지만 치료 후 재발률이 높 은 실정이다[12]. 이에 대한 대안으로, KTP 레이저를 성대 육 아종에 대한 치료의 대안으로 이용한 연구 결과에 따르면, 병 변의 크기에 따라 평균 $1.65 \pm 1.16$ 회의 KTP 레이저 치료를 받 은 26 명의 성대 육아종 환자에서 완전 관해가 $73.1 \%$ 를 보인 다고 하였다[13]. 따라서 KTP 레이저를 기존의 다른 치료에 도 불구하고 재발하는 성대 육아종을 치료할 수 있는 대안으 로 고려할 수 있겠다. 본 저자의 경험은 성대 육아종 레이저 치료 시에 과도한 에너지를 전달하여 육아종을 태워 없애는 방법보다는 적절한 에너지를 전달하여 점막 표면이 탈색되는 정도만 치료하였을 경우 시간이 경과하면서 저절로 퇴화 및 소 멸하는 양상이 보여 후자의 방법을 더 추천하는 바이다(Fig. 3). 즉 "Less is more"라는 개념으로 접근하는 것이 더 나은 방법 이다.

\section{성대구증}

성대구증은 성대 상피층이 선척적, 후천적 원인에 의해서 성 대 인대와 유착되어 성대 진동이 없어지면서 발생하는 난치 성 음성 질환이다. 성대에 열 에너지가 전해져서 $7^{\circ} \mathrm{C}-8^{\circ} \mathrm{C}$ 온 도가 상승하게 되면 점막과 인대 사이의 유동성이 증가되어 성대 점막 운동이 향상될 수 있다는 보고가 있다[14]. 이것은 콜라겐의 재배치 및 재합성에 의해 성대의 점막 표피가 재생 되는 기전으로 설명할 수 있다. 따라서 난치성 음성 질환인 성 대구증 치료에 KTP 레이저를 이용할 수 있는 근거가 되었다. 최근에 후두미세수술 세팅으로 혈관 용해성 레이저를 이용하 여 79명의 성대구증 환자를 치료한 보고에 따르면 음성 지표 가 술 후 시간이 경과하면서 지속적으로 호전되는 양상을 보 인다고 하였다[15]. 지금까지 성대구증 치료는 거의 대부분 전
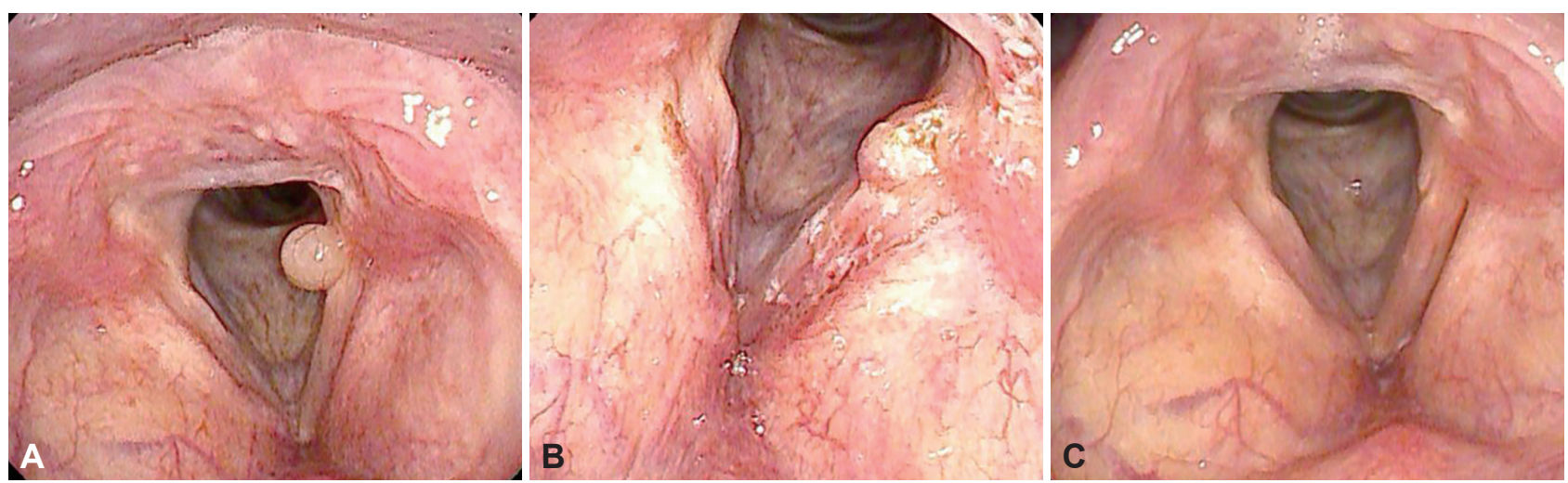

Fig. 3. Serial change of vocal granuloma after treatment of potassium-titanyl-phosphate (KTP) laser. A: Preoperative laryngoscope of vocal granuloma. B: Immediate laryngoscope after the treatment of KTP laser. C: Post-treatment laryngoscope 2 months after KTP laser. 
신마취에서 진행되었으나 외래에서 스트로보스코피를 통해 정확히 병변을 파악한 후 외래 기반 후두 수술의 방법으로 성 대구증이 있는 부위에 KTP 레이저를 조사할 수 있다. 이때 성대구증의 점막이 탈색되는 정도의 에너지가 전달되는 것이 좋다. 또한 첫 수술로 증상 호전이 없을 경우에는 외래에서 정 기적으로 재치료를 함으로써 성대 점막 표피의 재생을 더 촉 진시킬 수 있다. 그러나 이와 같은 처치에도 불구하고 음성 호 전 정도는 개인에 따라 차이가 있어 성대구증은 여전히 난치 성 질환이므로 KTP 레이저 치료에 반응이 없는 경우에는 다 른 추가 치료를 고려하는 것이 필요하다.

\section{라인케 부종, 재발성 호흡기 유두종, 성대 백반증}

성대 점막 혈관의 확장 및 투과력 증가로 부종이 생기고 점 막하층에 유리화 현상(hyaline degeneration)이 발생되어 생 기는 라인케 부종에도 KTP 레이저를 이용할 수 있다[16]. 이 보고에 따르면 평균 $157 \mathrm{~J}$ (최대 $200 \mathrm{~J}$ )의 에너지가 전달되었고, 유의미한 수술 전후의 음성 장애 지수의 호전을 보였으며, 외 래에서 시행한 군과 미세후두수술로 시행한 군 사이의 음성 향상 지수의 차이는 관찰되지 않았다. 성대 백반증인 경우 외 래 기반 KTP 레이저 수술 1 치료 보고에 따르면 외래 경과 관 찰 중 평균 2회, 7.6 개월의 간격을 두고 반복적인 $\mathrm{KTP}$ 레이저 치료를 하여 음성 보존과 $77.1 \%$ 의 성공적인 치료 결과를 보 였다[17]. Zeitels 등[3]이 후두 유두종과 성대 백반증에 대해 외래 기반 KTP 레이저 후두 수술을 처음으로 보고하였다. 이 연구 결과에서 성대 백반증은 약 $62 \%$ 의 환자에서 수술 후 $75 \%$ 이상의 치료 효과를 보였고, 유두종 환자에서는 증상이 재발할 때 마다 'touch-up' 처치를 통해 모두 치료할 수 있었 다고 보고 하였다. 이와 같은 질환은 다른 질환에 비해 한 번 의 수술보다는 외래에서 여러 차례의 수술이 필요하다. 또한 암으로의 변환이 가능하기 때문에 면밀한 추적 관찰이 필요 하고 이때 조직검사가 필요할 수 있는데, 겸자를 후두 내시경 의 채널에 삽입하여 조직을 일부 채취한 후 병리 조직 검사를 시행 할 수 있다. 그러나 유두종과 성대 백반증에서 초기 치 료로 외래 기반 KTP 레이저 수술을 적용하기 보다는, 전신마 취 후 후두 미세수술로 모두 제거 후 경과 관찰 중 병변이 재 발되었을 경우 전신마취의 빈도를 줄이기 위해 재치료의 일 환으로 사용하는 것이 더 보편적이다.

\section{외래 수술 시 주의 사항 및 수술 후 관리}

환자의 선택이 무엇보다 중요하다. 조절되지 않는 구역 반 사와 다량의 점액 분비물 때문에 수술을 성공적으로 시행할 수 없는 경우가 $10 \%$ 내외로 알려져 있다[18]. 보통 수술 전 후 두 내시경 검사에서도 민감한 반응을 보여 관찰이 어려운 환
자는 수술할 때도 비슷한 증상을 보이므로 외래 수술에 적합 하지 않는 경우가 많다. 경우에 따라서는 수술 전 30분 전에 로라제팜(lorazepam)과 같은 항불안증약을 주사한 후 보다 높은 성공률을 보인다고 하였다[19]. 국소마취로 시행되기 때 문에 전신마취와 관련된 합병증은 발생하지 않으나, 수술 중 환자가 앉은 자세에서 긴장을 하는 경우 간혹 혈압이 떨어지 면서 실신을 일으킬 수 있다. 따라서 환자의 긴장을 최대한 풀 어주기 위해 지속적으로 대화를 나누는 것이 좋은 대안이 된 다. 내시경을 후두 내로 진입할 때 후두개 근처와 닿는 경우가 있는데, 이럴 경우에는 후두 반사가 야기되어 수술을 어렵게 만들거나 심지어 계획된대로 모두 끝내지 못하는 경우가 있 다. 가능한 시간을 두고 충분한 후두마취를 하면서 수술 전 후두 반사가 심할 경우에는 수술이 시행될 수 없음을 사전 동 의를 받는 것이 필요하다.

수술이 끝난 후 약 1 시간 정도는 흡인의 위험성 때문에 음 식 섭취를 제한한다. 성대 병변을 치료한 후 하루 정도는 음성 사용을 자제하고 1 주일에 걸쳐 조금씩 음성 사용을 늘려가는 것이 필요하며, 그 외 후두개 낭종이나 인두 병변인 경우에는 음식 섭취를 1-2일까지 조심해야 한다. 또한 통증이 있을 수 있으므로 진통제를 같이 복용하는 것이 좋다.

\section{외래에서 시행하는 KTP 레이저 수술의 합병증}

$\mathrm{KTP}$ 레이저의 특성상 $\mathrm{CO}_{2}$ 레이저와 달리 정밀한 병변 절 제는 어렵다. 따라 병변이 너무 작거나 수술 중 성대가 많이 움직일 경우에는 KTP 레이저가 주위 정상 조직에도 에너지 가 전달되어 성대 점막의 경화를 유발시킬 수 있다. 성대 점막 에 과도한 레이저 에너지가 집중되었을 때 점막손상으로 성 대 섬유화, 성대 협착 등이 발생하여 발성 장애나 호흡 곤란 을 일으킨다. 외래에서 시행한 레이저 후두 수술로 97예의 성 대 용종을 치료한 보고에 따르면 성대 부종이나 혈종 및 궤 양 등이 약 8\%에서 보고되었다[20]. 한편 144명의 성대 용종 환자를 치료한 결과에서 약 $11 \%$ 의 치료 실패(재수술, 후두미 세수술로 제거)를 보였다고 하였다[8].

\section{결 론}

외래에서 시행할 수 있는 KTP 레이저 후두 수술은 국소마 취 기술의 발달과 술기 자체의 다양화로 점차 적용 가능한 질 환들이 확대되고 있다. 외래에서 시행하는 후두 수술은 기존 의 수술 방법에 비해 안전하면서 비용을 절감할 수 있는 방법 이며 또한 치료면에서도 비슷한 결과를 보이고 있다. 병변의 종류에 따라 레이저의 출력이나 주기 등과 같은 에너지 전달 변수의 표준화도 앞으로 풀어야 할 과제이며 이를 위해서는 
보다 많은 임상 데이터가 축적되어야 할 것이다.

중심 단어: Potassium-titanyl-phosphate; 레이저; 성대 용 종; 양성 후두 병변; 후두 수술; 외래 기반 수술.

Acknowledgments

None

Conflicts of Interest

The author has no financial conflicts of interest.

\section{REFERENCES}

1. Tibbetts KM, Simpson CB. Office-based 532-nanometer pulsed potassium-titanyl-phosphate laser procedures in laryngology. Otolaryngol Clin North Am 2019;52(3):537-57.

2. Kim HT, Auo HJ. Office-based $585 \mathrm{~nm}$ pulsed dye laser treatment for vocal polyps. Acta Otolaryngol 2008;128(9):1043-7.

3. Zeitels SM, Akst LM, Burns JA, Hillman RE, Broadhurst MS, Anderson RR. Office-based 532-nm pulsed KTP laser treatment of glottal papillomatosis and dysplasia. Ann Otol Rhinol Laryngol 2006;115(9): 679-85.

4. Ayala C, Selig M, Faquin W, Franco RA Jr. Ultrastructural evaluation of 585-nm pulsed-dye laser-treated glottal dysplasia. J Voice 2007;21(1): 119-26.

5. Shoffel-Havakuk H, Sadoughi B, Sulica L, Johns MM 3rd. In-office procedures for the treatment of benign vocal fold lesions in the awake patient: A contemporary review. Laryngoscope 2019;129(9):2131-8.

6. Zeitels SM, Akst LM, Bums JA, Hillman RE, Broadhurst MS, Anderson RR. Pulsed angiolytic laser treatment of ectasias and varices in singers. Ann Otol Rhinol Laryngol 2006;115(8):571-80.

7. Mallur PS, Johns MM 3rd, Amin MR, Rosen CA. Proposed classification system for reporting 532-nm pulsed potassium titanyl phosphate laser treatment effects on vocal fold lesions. Laryngoscope 2014; 124(5):1170-5.

8. Del Signore AG, Shah RN, Gupta N, Altman KW, Woo P. Complications and failures of office-based endoscopic angiolytic laser surgery treatment. J Voice 2016;30(6):744-50.
9. Wang CT, Huang TW, Liao LJ, Lo WC, Lai MS, Cheng PW. Officebased potassium titanyl phosphate laser-assisted endoscopic vocal polypectomy. JAMA Otolaryngol Head Neck Surg 2013;139(6):610-6.

10. Wang CT, Liao LJ, Huang TW, Lo WC, Cheng PW. Comparison of treatment outcomes of transnasal vocal fold polypectomy versus microlaryngoscopic surgery. Laryngoscope 2015;125(5):1155-60.

11. Helman SN, Pitman MJ. Office-based 532-Nanometer pulsed potassium-titanyl-phosphate laser for marsupialization of laryngeal and vallecular mucoceles. Laryngoscope 2017;127(5):1116-8.

12. Karkos PD, George M, Van Der Veen J, Atkinson H, Dwivedi RC, Kim D, et al. Vocal process granulomas: A systematic review of treatment. Ann Otol Rhinol Laryngol 2014;123(5):314-20.

13. Dominguez LM, Brown RJ, Simpson CB. Treatment outcomes of inoffice KTP ablation of vocal fold granulomas. Ann Otol Rhinol Laryngol 2017;126(12):829-34.

14. Fanjul-Vélez F, Arce-Diego JL. Modeling thermotherapy in vocal cords novel laser endoscopic treatment. Lasers Med Sci 2008;23(2): 169-77.

15. Park YM, Lim JY, Kang MS, Choi HS. Treatment outcomes of angiolytic laser-assisted glottoplasty in patients with sulcus vocalis. Ann Otol Rhinol Laryngol 2019;128(5):377-83.

16. Young VN, Mallur PS, Wong AW, Mandal R, Staltari GV, GartnerSchmidt J, et al. Analysis of potassium titanyl phosphate laser settings and voice outcomes in the treatment of Reinke's edema. Ann Otol Rhinol Laryngol 2015;124(3):216-20.

17. Koss SL, Baxter P, Panossian H, Woo P, Pitman MJ. Serial in-office laser treatment of vocal fold leukoplakia: Disease control and voice outcomes. Laryngoscope 2017;127(7):1644-51.

18. Young VN, Smith LJ, Sulica L, Krishna P, Rosen CA. Patient tolerance of awake, in-office laryngeal procedures: A multi-institutional perspective. Laryngoscope 2012;122(2):315-21.

19. Anderson J, Bensoussan Y, Townsley R, Kell E. In-office endoscopic laryngeal laser procedures: A patient safety initiative. Otolaryngol Head Neck Surg 2018;159(1):136-42.

20. Lin YH, Wang CT, Lin FC, Liao LJ, Lo WC, Cheng PW. Treatment outcomes and adverse events following in-office angiolytic laser with or without concurrent polypectomy for vocal fold polyps. JAMA Otolaryngol Head Neck Surg 2018;144(3):222-30. 